Jurnal Ilmiah Matematika dan Pendidikan Matematika (JMP)

Vol. 13 No. 2, Desember 2021, hal. 93-104

ISSN (Cetak) : 2085-1456; ISSN (Online) : 2550-0422

\title{
PREDIKSI BERAT TUBUH SAPI PERAH FRIESIAN-HOLSTEIN MENGGUNAKAN MODEL VON BERTALANFFY
}

\author{
Niken Larasati \\ Jurusan Matematika, Universitas Jenderal Soedirman \\ niken.larasati@unsoed.ac.id, \\ Tri Puji Sulistyoningrum \\ Jurusan Matematika, Universitas Jenderal Soedirman \\ Mutia Nur Estri \\ Jurusan Matematika, Universitas Jenderal Soedirman \\ Idha Sihwaningrum \\ Jurusan Matematika, Universitas Jenderal Soedirman \\ Rina Reorita \\ Jurusan Matematika, Universitas Jenderal Soedirman
}

\begin{abstract}
In this paper, we predict the weight of Friesian-Holstein dairy cows by using Von Bertalanffy model. The metabolism rate in the model includes the anabolism and catabolism rate. The prediction is important to determine the age of the first cows mating since an improper age of the first mating will result in the low production of milk and a non ideal weight of the cow calves. The result of the simulation shows that the constant of anabolism is 0.3854, and the constant of catabolism is 0.0438. By using these constans, it is found that the result of the prediction has an average absolute error of $4,9708 \%(6,5358 \mathrm{~kg})$. Furthermore, it is found that the cows can be mated when their weight is between $273,9152 \mathrm{~kg}$ and $303,2340 \mathrm{~kg}$, that is when their age is between 59 and 66 weeks (or between 14 and 16 months).
\end{abstract}

Keywords: Von Bertalanffy's model, Friesian-Holstein dairy cow, anabolism and catabolism, age of mating, weight.

\begin{abstract}
ABSTRAK. Pada makalah ini dibahas mengenai prediksi berat tubuh sapi perah Friesian-Holstein menggunakan model Von Bertalanffy. Laju metabolisme pada model terdiri dari anabolisme dan katabolisme. Prediksi berat tubuh sapi perah ini penting karena dapat digunakan untuk menentukan usia kawin pertama kali sapi perah FH. Usia kawin pertama yang tidak tepat dapat menyebabkan produksi susu yang rendah dan tidak tercapainya berat tubuh pedet yang ideal. Dari hasil simulasi diperoleh konstanta anabolisme sebesar 0,3854 dan konstanta katabolisme sebesar 0,0438. Dengan konstanta tersebut, diperoleh rata-rata kesalahan absolut sebesar 4,9708\% (6,5358 kg). Selanjutnya, diperoleh hasil bahwa sapi dapat dikawinkan pada saat memiliki berat tubuh $273,9152 \mathrm{~kg}$ sampai 303,2340 kg dengan umur 59-66 minggu (14-16 bulan).
\end{abstract}


Kata Kunci: Model Von Bertalanffy, sapi perah Friesian-Holstein, anabolisme dan katabolisme, usia kawin, berat tubuh.

\section{PENDAHULUAN}

Sapi perah peranakan Friesian-Holstein $(\mathrm{FH})$ merupakan sapi perah penghasil susu yang banyak dipelihara di Indonesia karena jenis sapi tersebut dapat memproduksi susu dalam volume yang besar dan mengandung kadar lemak yang rendah. Untuk menghasilkan susu sapi yang optimal, diperlukan nutrisi pakan yang baik dari segi kualitas maupun kuantitas. Nutrisi pakan tersebut dapat berfungsi sebagai penyedia energi yang diperoleh melalui proses metabolisme. Proses metabolisme adalah semua reaksi kimia di dalam tubuh yang terdiri dari proses anabolisme dan katabolisme (Guyton dan Hall, 1997: 1133). Karena energi dihasilkan melalui proses metabolisme dalam tubuh, maka perubahan berat tubuh hewan terhadap waktu dapat dipengaruhi oleh laju metabolisme. Menurut France dan Thornley (2007: 152), hal tersebut dapat dimodelkan secara matematika menggunakan model Von Bertalanffy. Model Von Bertalanffy telah banyak digunakan untuk memprediksi perubahan berat tubuh hewan seperti yang dapat dilihat pada (James, 1991; Hossein-Zadeh dan Golshani, 2016; Pagalay, dkk., 2016), dan model pertumbuhan tumor (Kuhleitner,dkk., 2019). Prediksi berat tubuh sapi perah FH menggunakan model Von Bertalanffy ini penting dilakukan karena hasil prediksi dapat digunakan untuk menentukan usia kawin pertama kali sapi perah FH. Usia kawin pertama yang tidak tepat dapat menyebabkan produksi susu yang rendah dan tidak tercapainya berat tubuh pedet yang ideal.

\section{HASIL DAN PEMBAHASAN}

\subsection{Model Von Bertalanffy}

Berdasarkan asumsi bahwa makanan yang diberikan kepada hewan ternak tidak terbatas dan pertumbuhan tubuh hewan bersifat irreversible, maka laju perubahan berat tubuh terhadap waktu yang mengikuti model dua kompartemen tertutup adalah

$$
\frac{d W}{d t}=h(W)
$$


dengan $W$ menyatakan berat tubuh dan $t$ menyatakan waktu. Laju perubahan berat tubuh hewan dipengaruhi oleh banyak faktor yang salah satunya adalah proses metabolisme di dalam tubuh. Dari proses metabolisme tersebut akan dihasilkan energi. Laju metabolisme pada hewan mamalia yang berdarah panas dapat menghasilkan kalori sekitar $1000 \mathrm{kkal} / \mathrm{m}^{2}$ luas permukaan tubuh setiap harinya (Bertalanffy, 1957), yang dikenal dengan istilah surface rule. Proses metabolisme terdiri dari proses anabolisme dan proses katabolisme.

Menurut Campbell, dkk. (2004: 12), laju metabolisme dalam tubuh hewan dapat diketahui dengan menghitung jumlah oksigen yang dikonsumsi oleh hewan pada saat proses respirasi. Pada proses respirasi tersebut oksigen akan masuk ke dalam tubuh yang kemudian digunakan untuk membantu proses oksidasi untuk membentuk energi dalam tubuh. Proses oksidasi merupakan salah satu proses anabolisme. Selanjutnya, proses anabolisme pada tiap jenis hewan berbeda-beda sesuai dengan proses respirasi pada hewan tersebut. Pada hewan mamalia proses respirasinya sesuai dengan surface rule dan laju perubahan berat tubuh yang dipengaruhi oleh anabolisme diberikan oleh

$$
\frac{d W}{d t}=\mu W^{2 / 3}
$$

dengan $\mu$ merupakan konstanta anabolisme. Selanjutnya, proses katabolisme adalah proses penguraian energi. Laju perubahan berat tubuh yang dipengaruhi proses anabolisme dan katabolisme adalah

$$
\frac{d W}{d t}=\mu W^{2 / 3}-\lambda W
$$

dengan $0<\lambda<\mu$. Persamaan (1) merupakan model Von Bertalanffy untuk hewan mamalia. Dengan menggunakan metode peubah terpisah, penyelesaian model Von Bertalanffy pada persamaan (1) diberikan oleh

$$
W=\left((\mu / \lambda)-\left((\mu / \lambda)-W_{0}^{(1 / 3)}\right) e^{-(1 / 3) t t}\right)^{3} .
$$

Perilaku penyelesaian model pada persamaan (2) untuk jangka waktu yang lama ditentukan oleh

$$
W_{f}=(\mu / \lambda)^{3} .
$$


Hal ini berarti bahwa untuk jangka waktu yang lama bobot hewan ternak akan mendekati batas maksimumnya, yaitu $W_{f}=(\mu / \lambda)^{3}$. Namun, laju pertumbuhan akan mulai menurun setelah mencapai titik infleksi, yaitu

$$
\left(\frac{3}{\lambda} \ln \left(\frac{\left(\frac{\mu}{\lambda}\right)-W_{0}^{(1 / 3)}}{\left(\frac{\mu}{3 \lambda}\right)}\right), \frac{8 \mu^{3}}{27 \lambda^{3}}\right) .
$$

Selanjutnya, misalkan $W_{0}$ merupakan berat tubuh pada saat $t=0$, maka grafik penyelesaian model Von Bertalanffy dapat dilihat pada Gambar 1.

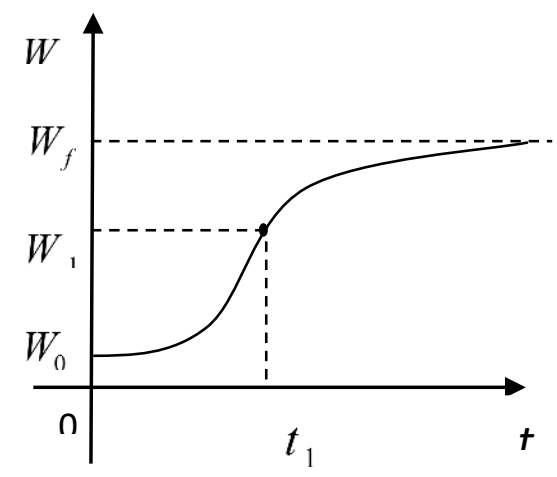

Gambar 1. Grafik penyelesaian model Von Bertalanffy.

\subsection{Prediksi Berat Tubuh Sapi}

Berat tubuh sapi FH akan diprediksi menggunakan data yang diperoleh dari BBPTUHPT Baturraden. Rata-rata berat tubuh sapi perah FH diberikan pada Tabel 1. Menurut Bertalanffy (1957), konstanta anabolisme dan katabolisme pada model pertumbuhan diperoleh berdasarkan siklus protein turnover. Protein turnover memberikan hubungan antara sintesis protein (anabolisme) dan pemecahan atau degradasi protein (katabolisme). Lobley, dkk. (1980) menyebutkan bahwa pada sapi dengan berat $628 \mathrm{~kg}$, protein turnover yang terjadi dalam tubuh sapi tersebut sebesar $3,7 \mathrm{~g} / \mathrm{kg}$ berat tubuh/hari $=3,7 \mathrm{~g} \times 628 / 628 \mathrm{~kg}$ $=2,3236 \mathrm{~kg} / 628 \mathrm{~kg}$ berat tubuh/hari. Sintesis protein (anabolisme) $=2 \mathrm{~kg} / \mathrm{hari}=2$ $\mathrm{kg} / 628 \mathrm{~kg}$ berat tubuh/hari. Degradasi protein (katabolisme) $=2,3236-2=$ $0,3236 \mathrm{~kg} / 628 \mathrm{~kg}$ berat tubuh/hari. Jadi, persentase anabolisme yang terjadi pada sapi dengan berat tubuh $628 \mathrm{~kg}$ adalah sebesar $0,32 \%$ berat tubuh dan persentase katabolisme sebesar $0,05 \%$ berat tubuh. Selanjutnya, persentase anabolisme 
dijadikan sebagai konstanta anabolisme, yaitu $\mu=0,32$ dan persentase katabolisme dijadikan sebagai konstanta katabolisme, yaitu $\lambda=0,05$.

Tabel 1. Data berat tubuh sapi perah FH

\begin{tabular}{|c|c|c|c|c|c|}
\hline No. & $\begin{array}{l}\text { Umur }(t) \\
(\text { Minggu })\end{array}$ & $\begin{array}{c}\text { Berat Tubuh }(W) \\
(\mathrm{kg})\end{array}$ & No. & $\begin{array}{l}\text { Umur }(t) \\
(\text { Minggu })\end{array}$ & $\begin{array}{c}\text { Berat Tubuh }(W) \\
(\mathrm{kg})\end{array}$ \\
\hline 1 & 0 & 37,43 & 29 & 28 & 152,09 \\
\hline 2 & 1 & - & 30 & 29 & 170 \\
\hline 3 & 2 & - & 31 & 30 & 171,33 \\
\hline 4 & 3 & - & 32 & 31 & 147 \\
\hline 5 & 4 & 55,4 & 33 & 32 & 157,71 \\
\hline 6 & 5 & 54,23 & 34 & 33 & 172,8 \\
\hline 7 & 6 & 63,5 & 35 & 34 & 168,11 \\
\hline 8 & 7 & 63,286 & 36 & 35 & 167,57 \\
\hline 9 & 8 & 69 & 37 & 36 & 174,4 \\
\hline 10 & 9 & 65 & 38 & 37 & 168 \\
\hline 11 & 10 & 69 & 39 & 38 & 183,1 \\
\hline 12 & 11 & 78,1 & 40 & 39 & 197,5 \\
\hline 13 & 12 & 81 & 41 & 40 & 189,182 \\
\hline 14 & 13 & 84,286 & 42 & 41 & 193,5 \\
\hline 15 & 14 & 83,25 & 43 & 42 & 198,375 \\
\hline 16 & 15 & 99,125 & 44 & 43 & 206,25 \\
\hline 17 & 16 & 107,25 & 45 & 44 & 208,3 \\
\hline 18 & 17 & 99,25 & 46 & 45 & 206,25 \\
\hline 19 & 18 & 106 & 47 & 46 & 219,78 \\
\hline 20 & 19 & 110 & 48 & 47 & 194,33 \\
\hline 21 & 20 & 107,125 & 49 & 48 & 222,67 \\
\hline 22 & 21 & 112,11 & 50 & 49 & 222,67 \\
\hline 23 & 22 & 119,4 & 51 & 50 & 241,5 \\
\hline 24 & 23 & 123,17 & 52 & 51 & 236,57 \\
\hline 25 & 24 & 135,25 & 53 & 52 & 243,75 \\
\hline 26 & 25 & - & 54 & 53 & 250,4 \\
\hline 27 & 26 & 131,58 & 55 & 54 & 266,875 \\
\hline 28 & 27 & 141,33 & 56 & 55 & 248,75 \\
\hline
\end{tabular}

Selanjutnya, dengan mensubstitusikan nilai $\mu=0,32$ dan $\lambda=0,05$ serta berat awal $W_{0}=37,43$ ke persamaan (3), diperoleh prediksi berat tubuh sapi perah $\mathrm{FH}$ seperti yang ditunjukkan oleh grafik pada Gambar 2. Grafik pada Gambar 2 menunjukkan bahwa pertambahan berat tubuh cukup kecil setelah sapi mencapai 
$77,6723 \mathrm{~kg}$ pada umur 21,5440 minggu dan untuk jangka waktu yang lama berat tubuh maksimum sapi perah FH hanya mencapai 262,1440 kg. Hasil prediksi berat tubuh sapi perah FH yang diperoleh pada Tabel 2 terlalu rendah bila dibandingkan dengan data berat tubuh sapi perah FH pada Tabel 1. Hal ini menunjukkan bahwa konstanta anabolisme dan katabolisme dari Lobley, dkk. (1980) tidak sesuai untuk memprediksi berat tubuh sapi perah FH di BBPTUHPT Baturraden. Hal tersebut antara lain dikarenakan iklim serta komposisi pakan yang berbeda antara Indonesia dengan di luar negeri yang menyebabkan siklus protein turnover berbeda. Oleh karena itu, perlu dilakukan simulasi untuk memperoleh konstanta anabolisme dan katabolisme yang sesuai untuk memprediksi berat tubuh sapi perah FH di BBPTUHPT Baturraden.

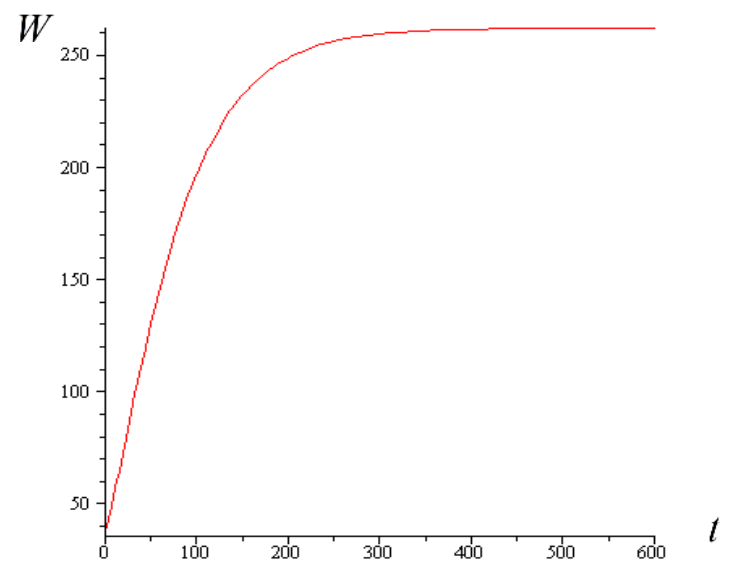

Gambar 2 Grafik pertumbuhan berat tubuh sapi dengan konstanta anabolisme 0,32 dan konstanta katabolisme 0,05.

Simulasi dilakukan dengan membandingkan konstanta-konstanta di persekitaran konstanta yang telah diketahui yaitu $\mu=0,32$ dan $\lambda=0,05$. Simulasi dibatasi sampai $1 \%$ dari persentase kesalahan absolut berat tubuh sapi perah $\mathrm{FH}$ pada umur 52 minggu. Dari hasil simulasi, diperoleh konstanta anabolisme $\mu=0,3854$ dan katabolisme $\lambda=0,0438$ dengan prediksi berat tubuh pada umur 52 minggu adalah $243,7188 \mathrm{~kg}$ dan persentase kesalahan absolutnya $0,0128 \%$. Prediksi berat tubuh sapi per minggu dan persentase kesalahan absolutnya ditampilkan pada Tabel 2 berikut. 
Tabel 2. Perbandingan antara berat tubuh sebenarnya dan hasil prediksi berat tubuh sapi perah pada minggu 1 sampai minggu 55 .

\begin{tabular}{|c|c|c|c|c|}
\hline Minggu & $\begin{array}{c}\text { Berat Tubuh } \\
\text { Sapi Perah FH } \\
(\mathrm{kg})\end{array}$ & $\begin{array}{l}\text { Prediksi Berat Tubuh } \\
\text { Sapi Perah FH (kg) }\end{array}$ & $\begin{array}{c}\text { Prediksi } \\
\text { Pertambahan } \\
\text { Berat Tubuh } \\
\text { Sapi Perah FH } \\
\text { (kg) }\end{array}$ & $\begin{array}{c}\text { Persentasi } \\
\text { Kesalahan } \\
\text { Absolut }\end{array}$ \\
\hline 1 & - & 40,1475 & - & - \\
\hline 2 & - & 42,9505 & 2,8030 & - \\
\hline 3 & - & 45,8377 & 2,8872 & - \\
\hline 4 & 55,4 & 48,8068 & 2,9691 & $11,9010 \%$ \\
\hline 5 & 54,23 & 51,8557 & 3,0489 & $4,3781 \%$ \\
\hline 6 & 63,5 & 54,9821 & 3,0489 & $13,4139 \%$ \\
\hline 7 & 63,286 & 58,1838 & 3,1264 & $8,0622 \%$ \\
\hline 8 & 69 & 61,4583 & 3,2745 & $10,9300 \%$ \\
\hline 9 & 65 & 64,8033 & 3,3450 & $0,026 \%$ \\
\hline 10 & 69 & 68,2165 & 3,4132 & $1,1355 \%$ \\
\hline 11 & 78,1 & 71,6954 & 3,4789 & $8,2005 \%$ \\
\hline 12 & 81 & 75,2377 & 3,5423 & $7,1139 \%$ \\
\hline 13 & 84,286 & 78,8410 & 3,6033 & $6,4601 \%$ \\
\hline 14 & 83,25 & 82,5029 & 3,6618 & $0,8974 \%$ \\
\hline 15 & 99,125 & 86,2209 & 3,7180 & $13,0180 \%$ \\
\hline 16 & 107,25 & 89,9927 & 3,7718 & $16,0907 \%$ \\
\hline 17 & 99,25 & 93,8159 & 3,8232 & $5,4752 \%$ \\
\hline 18 & 106 & 97,6881 & 3,8722 & $7,8414 \%$ \\
\hline 19 & 110 & 101,6070 & 3,9189 & $7,6299 \%$ \\
\hline 20 & 107,125 & 105,5704 & 3,9633 & $1,4512 \%$ \\
\hline 21 & 112,11 & 109,5758 & 4,0054 & $2,2604 \%$ \\
\hline 22 & 119,4 & 113,6211 & 4,0453 & $4,8399 \%$ \\
\hline 23 & 123,17 & 117,7039 & 4,0828 & $4,4378 \%$ \\
\hline 24 & 135,25 & 121,8221 & 4,1182 & $9,9282 \%$ \\
\hline 25 & - & 125,9736 & 4,1514 & - \\
\hline 26 & 131,58 & 130,1561 & 4,1825 & $1,0822 \%$ \\
\hline 27 & 141,33 & 134,3675 & 4,2115 & $4,99264 \%$ \\
\hline 28 & 152,09 & 138,6059 & 4,2384 & $8,88659 \%$ \\
\hline 29 & 170 & 142,8691 & 4,2632 & $15,9593 \%$ \\
\hline 30 & 171,33 & 147,1552 & 4,2861 & $14,1101 \%$ \\
\hline 31 & 147 & 151,4622 & 4,3070 & $3,0355 \%$ \\
\hline 32 & 157,71 & 155,7881 & 4,3260 & $1,2186 \%$ \\
\hline 33 & 172,8 & 160,1313 & 4,3431 & $7,3314 \%$ \\
\hline 34 & 168,11 & 164,4897 & 4,3584 & $2,1535 \%$ \\
\hline 35 & 167,57 & 168,8616 & 4,3719 & $0,7708 \%$ \\
\hline 36 & 174,4 & 173,2453 & 4,3837 & $0,6621 \%$ \\
\hline
\end{tabular}




\begin{tabular}{lllll}
37 & 168 & 177,6390 & 4,3937 & $5,7375 \%$ \\
38 & 183,1 & 182,0411 & 4,4021 & $0,5783 \%$ \\
39 & 197,5 & 186,4500 & 4,4089 & $5,5949 \%$ \\
40 & 189,182 & 190,8641 & 4,4141 & $0,8891 \%$ \\
41 & 193,5 & 195,2818 & 4,4177 & $0,9208 \%$ \\
42 & 198,375 & 199,7016 & 4,4199 & $0,6687 \%$ \\
43 & 206,25 & 204,1222 & 4,4206 & $1,0316 \%$ \\
44 & 208,3 & 208,5421 & 4,4198 & $0,1162 \%$ \\
45 & 206,25 & 212,9598 & 4,4178 & $3,2532 \%$ \\
46 & 219,78 & 217,3741 & 4,4143 & $1,0947 \%$ \\
47 & 194,33 & 221,7838 & 4,4096 & $14,1274 \%$ \\
48 & 222,67 & 226,1874 & 4,4037 & $1,5797 \%$ \\
49 & 222,67 & 230,5839 & 4,3965 & $3,5541 \%$ \\
50 & 241,5 & 234,9721 & 4,3882 & $2,7031 \%$ \\
51 & 236,57 & 239,3508 & 4,3787 & $1,1754 \%$ \\
52 & 243,75 & 243,7188 & 4,3681 & $0,0128 \%$ \\
53 & 250,4 & 248,0753 & 4,3565 & $0,9284 \%$ \\
54 & 266,875 & 252,4191 & 4,3438 & $5,4167 \%$ \\
55 & 248,75 & 256,7493 & 4,3302 & $3,2158 \%$ \\
\hline
\end{tabular}

Pada Tabel 2, diperoleh persentase kesalahan absolut minimum yaitu 0,0128\% sehingga selisih antara data sebenarnya dengan hasil prediksi adalah 0,0312 kg; dan persentase kesalahan absolut maksimum adalah 16,0907\%, yang berarti selisih antara data sebenarnya dengan prediksi adalah 17,2573 kg. Sementara itu, rata-rata persentase kesalahan absolut adalah $4,9708 \%$, yaitu ratarata selisih berat tubuh sebenarnya dengan hasil prediksi sebesar 6,5358 $\mathrm{kg}$. Jadi, konstanta anabolisme $\mu=0,3854$ dan konstanta katabolisme $\lambda=0,0438$ dapat digunakan untuk memprediksi pertumbuhan berat tubuh sapi perah FH. Dengan demikian, model Von Bertalanffy yang sesuai untuk memprediksi pertumbuhan berat tubuh sapi perah FH di BBPTUHPT Baturraden adalah

$$
\frac{d W}{d t}=0,3854 W^{2 / 3}-0,0438 W
$$

dengan penyelesaian model yaitu

$$
W(t)=\left(8,7991-5,4540 e^{-0,0146 t}\right)^{3} .
$$

Dengan menggunakan persamaan (4), dapat diperoleh prediksi berat tubuh sapi perah FH minggu ke-57 sampai minggu ke-100, seperti yang ditampilkan pada Tabel 3 berikut. 
Tabel 3 Prediksi berat tubuh sapi perah FH minggu ke-57 sampai hari ke-104

\begin{tabular}{|c|c|c|}
\hline Minggu & $\begin{array}{l}\text { Prediksi Berat Tubuh } \\
\text { Sapi Perah FH }(\mathrm{kg})\end{array}$ & $\begin{array}{c}\text { Prediksi Pertambahan Berat } \\
\text { Tubuh Sapi Perah FH (kg) }\end{array}$ \\
\hline 57 & 265,3650 & 4,3001 \\
\hline 58 & 269,6487 & 4,2837 \\
\hline 59 & 273,9152 & 4,2665 \\
\hline 60 & 278,1636 & 4,2484 \\
\hline 61 & 282,3933 & 4,2296 \\
\hline 62 & 286,6033 & 4,2101 \\
\hline 63 & 290,7931 & 4,1898 \\
\hline 64 & 294,9619 & 4,1688 \\
\hline 65 & 299,1091 & 4,1472 \\
\hline 66 & 303,2340 & 4,1249 \\
\hline 67 & 307,3360 & 4,1021 \\
\hline 68 & 311,4147 & 4,0786 \\
\hline 69 & 315,4693 & 4,0547 \\
\hline 70 & 319,4995 & 4,0302 \\
\hline 71 & 323,5047 & 4,0052 \\
\hline 72 & 327,4845 & 3,9798 \\
\hline 73 & 331,4384 & 3,9539 \\
\hline 74 & 335,3660 & 3,9276 \\
\hline 75 & 339,2669 & 3,9009 \\
\hline 76 & 343,1408 & 3,8738 \\
\hline 77 & 346,9872 & 3,8464 \\
\hline 78 & 350,8059 & 3,8187 \\
\hline 79 & 354,5966 & 3,7907 \\
\hline 80 & 358,3589 & 3,7623 \\
\hline 81 & 362,0927 & 3,7338 \\
\hline 82 & 365,7976 & 3,7049 \\
\hline 83 & 369,4735 & 3,6759 \\
\hline 84 & 373,1201 & 3,6466 \\
\hline 85 & 376,7373 & 3,6172 \\
\hline 86 & 380,3248 & 3,5875 \\
\hline 87 & 383,8825 & 3,5577 \\
\hline 88 & 387,4103 & 3,5278 \\
\hline 89 & 390,9081 & 3,4978 \\
\hline 90 & 394,3757 & 3,4676 \\
\hline 91 & 397,8130 & 3,4373 \\
\hline 92 & 401,2201 & 3,4070 \\
\hline 93 & 404,5967 & 3,3766 \\
\hline 94 & 407,9428 & 3,3461 \\
\hline 95 & 411,2584 & 3,3156 \\
\hline 96 & 414,5436 & 3,2851 \\
\hline 97 & 417,7981 & 3,2546 \\
\hline 98 & 421,0222 & 3,2240 \\
\hline 99 & 424,2157 & 3,1935 \\
\hline 100 & 427,3786 & 3,1630 \\
\hline
\end{tabular}


Dari Tabel 2 dan Tabel 3, dapat diketahui bahwa prediksi berat tubuh sapi perah FH terus meningkat namun pertambahan berat tubuhnya mengalami perubahan. Prediksi pertambahan berat tubuh sapi perah FH sebelum mencapai umur 43 minggu terus meningkat, sedangkan setelah melewati umur 43 minggu prediksi pertambahan berat tubuh menurun. Hal ini dikarenakan sapi perah $\mathrm{FH}$ telah memasuki masa pubertas. Masa pubertas biasanya ditandai dengan terjadinya birahi atau estrus. Menurut Tasripin, dkk. (2014) estrus pada sapi perah FH menyebabkan berkurangnya nafsu makan dan aktivitas hormonal yang berpotensi kurangnya asupan nutrisi ke dalam tubuh sapi sehingga menyebabkan pertambahan berat badannya menurun. Pada masa ini terjadi peralihan perubahan laju pertumbuhan yang awalnya percepatan menjadi perlambatan (Salman, dkk., 2015). Titik di saat terjadi perubahan dari percepatan menjadi perlambatan disebut titik infleksi. Dalam Gambar 1, titik infleksi dilambangkan dengan $\left(t_{1}, W_{1}\right)$ dan merupakan titik maksimum pertumbuhan sapi perah FH (karena pertumbuhannya berubah dari percepatan menjadi perlambatan). Dari persamaan (4), diperoleh titik infleksi $(42,5 ; 201,6972)$. Hal ini berarti laju pertumbuhan maksimum berat tubuh sapi perah FH terjadi pada umur 42,5 minggu dengan berat tubuh yaitu 201,6972 $\mathrm{kg}$.

Selanjutnya, kawin pertama sapi perah FH dara dipengaruhi oleh dua faktor utama, yaitu umur dan berat tubuh sapi perah FH. Namun, faktor yang lebih ditekankan adalah berat tubuh sapi karena apabila kawin pertama dilakukan pada sapi perah yang memiliki berat tubuh terlalu kecil hal ini akan berakibat sapi melahirkan pedet dengan berat tubuh yang tidak ideal dan kemungkinan mengalami kesulitan saat melahirkan. Selain itu, produksi susu sapi yang dihasilkan rendah (Makin, 2011: 42). Menurut Sudono (1999), sapi perah dapat dikawinkan pada berat tubuh 275-300 kg dengan umur 15-18 bulan. Berdasarkan prediksi berat tubuh sapi perah FH pada Tabel 3, sapi perah dapat dikawinkan pada berat tubuh 273,9152 kg sampai 303,2340 kg dengan umur 59-66 minggu atau sekitar 14-16 bulan. 


\section{KESIMPULAN DAN SARAN}

Prediksi berat tubuh sapi menggunakan model Von Bertalanffy yang disajikan pada makalah ini dapat dianggap sebagai prediksi yang valid karena rata-rata kesalahan mutlak antara data dengan hasil prediksi hanya sebesar $4,9708 \%(6,5358 \mathrm{~kg})$.

\section{DAFTAR PUSTAKA}

Bertalanffy, L.V., Quantitative Laws in Metabolism and Growth, Journal of The Quartely Review of Biology, 32(3) (1957), 217-231.

Campbell, N.A., Reece, J. B., Mitchell, B., Biology, $5^{\text {th }}$ Edition, Diterjemahkan oleh Manalu, W., Erlangga, 2004.

France, J., Thornley, J.H.M., Mathematical Models in Agriculture, $2^{\text {nd }}$ Editio,. CABI, 2007.

Guyton, A. C., Hall, J.E., Buku Ajar Fisiologi Kedokteran, Edisi Sembilan, EGC, 1997.

Hossein-Zadeh, N. G., Golshani, N., Comparison of Non-linear Models to Describe Growth of Iranian Guuilan Sheep, Rev. Colomb, Cience Pecu, 29 (2016) 199-209.

James, I. R., Estimation of Von Bertalanffy Growth Curve Parameters from Recapture Data, Biometrics, 47 (1991), 1519-1530.

Kuhleitner, M., Brunner, N., Nowak, W., Renner-Martin, K., Scheicher, K., Best Fitting tumor Growth Models of The Von Bertalanffy-Putter Type, BMC Cancer 19, 683 (2019).

Lobley, G.E., Reeds, P.J., Pennie, K., Whole Body and Tissue Protein Synthesis in Cattle, British Journal of Nutrition, 43(3) (1980), 491-502.

Makin, M., Tata Laksana Peternakan Sapi Perah, Graha Ilmu, 2011.

Pagalay, U., Budiawan, Anisyah, Analysis Von Bertalanffy Equation with Variation Coefficient, Proceedings of ICMSTEA, Makasar, 2016, 332338. 
Salman, L.B., Sumantri, C., Noor, R.R., Saefuddin, A., Talib, C., Kurva Pertumbuhan Sapi Friesian Holsten dari Lahir Sampai Siap Kawin Berdasarkan Tingkat Kelahiran, Jurnal Veteriner, 16(1) (2015), 96-106.

Sudono, A., Ilmu Produksi Ternak Perah. Institut Pertanian Bogor, Bogor, 1999.

Tasripin, D.S., Anang, A., Indrijani, H., Performans Pertumbuhan dan Bobot Sapi perah Betina Fries Holland Umur 0-18 Bulan, Universitas Padjajaran, 2014 